Supplement of

\title{
Molecular and spatial distributions of dicarboxylic acids, oxocarboxylic acids, and $\alpha$-dicarbonyls in marine aerosols from the South China Sea to the eastern Indian Ocean
}

Jing Yang et al.

Correspondence to: Pingqing Fu (fupingqing @tju.edu.cn)

The copyright of individual parts of the supplement might differ from the CC BY 4.0 License. 


\section{Linear correlations}

In order to investigate the origins and formation pathways of diacids and related compounds in marine aerosols, we examined the correlations between selected species and also conducted linear regression analyses for mass ratios of the selected chemical species. Moderate correlations were observed for $\mathrm{C}_{6}$ with $\mathrm{C}_{9}$ diacids in the EIO-WI and EIO-SL, and significant correlations over the SCS and Malacca regions. Such positive correlations indicate that the $\mathrm{C}_{6}$ diacid should have also been significantly generated from the biogenic VOCs such as cyclic olefins, in addition to the anthropogenic sources.

Hydroxy succinic acid (malic acid, $\left.\mathrm{hC}_{4}\right), \mathrm{C}_{4}$ and $\mathrm{C}_{3}$ diacids in the SCS correlated well with each other $(\mathrm{p}<0.05$; $\mathrm{R}^{2}=0.87$ for $\mathrm{hC}_{4} v s \mathrm{C}_{3}$ and $\mathrm{R}^{2}=0.78$ for $\mathrm{hC}_{4} v s \mathrm{C}_{4}$; Fig. S2a and $\mathrm{S} 2 \mathrm{~b}$ ). The formation of $\mathrm{C}_{3}$ diacid from $\mathrm{C}_{4}$ diacid through $\mathrm{hC}_{4}$ as an intermediate has been proposed by Kawamura and Sakaguchi (1999) and also observed in a laboratory study (Yang et al., 2008). A very good linear relationship of $\mathrm{hC}_{4}$ diacid with $\mathrm{C}_{4}$ diacid $\left(\mathrm{R}^{2}=0.85\right)$ and $\mathrm{C}_{2}$ diacid $\left(\mathrm{R}^{2}=0.78\right)$ has been reported in forest aerosols from central Europe, which have been attributed to insitu photochemical production from biogenic unsaturated fatty acids (Kourtchev et al., 2009). Therefore, the good correlations observed among $\mathrm{C}_{3}, \mathrm{C}_{4}$ and $\mathrm{hC}_{4}$ in the SCS implies that they were derived from common but mixed (both biogenic and anthropogenic) sources and the in-situ secondary formation might be more intensive, rather than the transformations from $\mathrm{C}_{4}$ to $\mathrm{C}_{3}$ via $\mathrm{hC}_{4}$ diacids. A significant linear correlation was also found between methylmalonic $\left(\mathrm{iC}_{4}\right)$ acid with $\mathrm{C}_{3}$ and $\mathrm{C}_{4}$ diacids. The branched chain diacids could come from the oxidation of isoprene released from the ocean surface. Such linear correlations also suggest that the diacids and related compounds were photochemical oxidation products of isoprene and biogenic unsaturated fatty acids in the MABL, and also confirm the intensive in-situ secondary formation of diacids and related species. A notable feature observed here is the significant $(\mathrm{p}<0.05)$ correlations between MeGly, Pyr, and $\omega \mathrm{C}_{2}$ with $\mathrm{C}_{3}$ and $\mathrm{C}_{4}$ diacids over Malacca, but not in other regions. Nguyen et al. (2010) found that $\mathrm{C}_{3}$ and $\mathrm{C}_{4}$ diacids were formed from isoprene oxidized by ozone based on the laboratory experiment. Furthermore, it has been reported that isoprene emission results in significant enhancement of SOA and $\mathrm{O}_{3}$ levels at coastal U.S. sites (Gantt et al., 2010). Hence, the loading of $\mathrm{C}_{3}$ and $\mathrm{C}_{4}$ diacids also should have been influenced by not only the unsaturated fatty acids but also the isoprene, at least in Malacca region.

The $\mathrm{C}_{2} /\left(\Sigma \mathrm{C}_{2}-\mathrm{C}_{10}\right)$ ratios showed negative relationships with $\mathrm{C}_{3}$ and $\mathrm{C}_{4}$ diacids over the SCS to EIO (Fig. S3a and $\mathrm{S} 3 \mathrm{~b}$ ). This phenomenon again confirms the formation of $\mathrm{C}_{2}$ diacid from $\mathrm{C}_{3}$ and $\mathrm{C}_{4}$ diacids by their photochemical transformations during long-range atmospheric transport. It is also worth noting that the $\mathrm{C}_{4} /\left(\Sigma \mathrm{C}_{2}-\right.$ $\mathrm{C}_{10}$ ) ratios showed a linear relationship with glutaric $\left(\mathrm{C}_{5}\right)$ acid in all regions, except the EIO-WI (Fig. S3c). Additionally, a similar variation trend is observed for the concentrations of $\mathrm{C}_{5}$ and $\mathrm{C}_{9}$ diacids in all regions, although 
50 they were not significant $\left(\mathrm{C}_{9}\right.$; Fig. S3d). Such positive relations reveal that they all should have been simultaneously produced significantly by in-situ photochemical reactions over the oceanic region, although we do not preclude the photochemical transformations of long-chain diacids to their lower homologues including $\mathrm{C}_{6}-\mathrm{C}_{4}$ diacids. Thus, the observed linear correlations among the relative abundances of $\mathrm{C}_{2}, \mathrm{C}_{3}, \mathrm{C}_{4}, \mathrm{C}_{5}$, and $\mathrm{C}_{9}$ infer that the long-chain as well as $\mathrm{C}_{3}$ and $\mathrm{C}_{4}$ diacids were mainly derived from biogenic emissions followed by the in-situ secondary reactions whereas the $\mathrm{C}_{2}$ diacid is mainly produced by the photochemical transformation of their higher over the SCS to EIO. The long-range transported air masses from the continental region that should be enriched with the anthropogenic emissions including oxidant species should have been promoted the oxidation of unsaturated fatty acids and BVOCs, resulting the enhanced levels of diacids and related compounds over the remote oceanic region. 
Table S1. Correlation matrices of selected diacids and related compounds in TSP collected during the NORC2015-10 cruise.

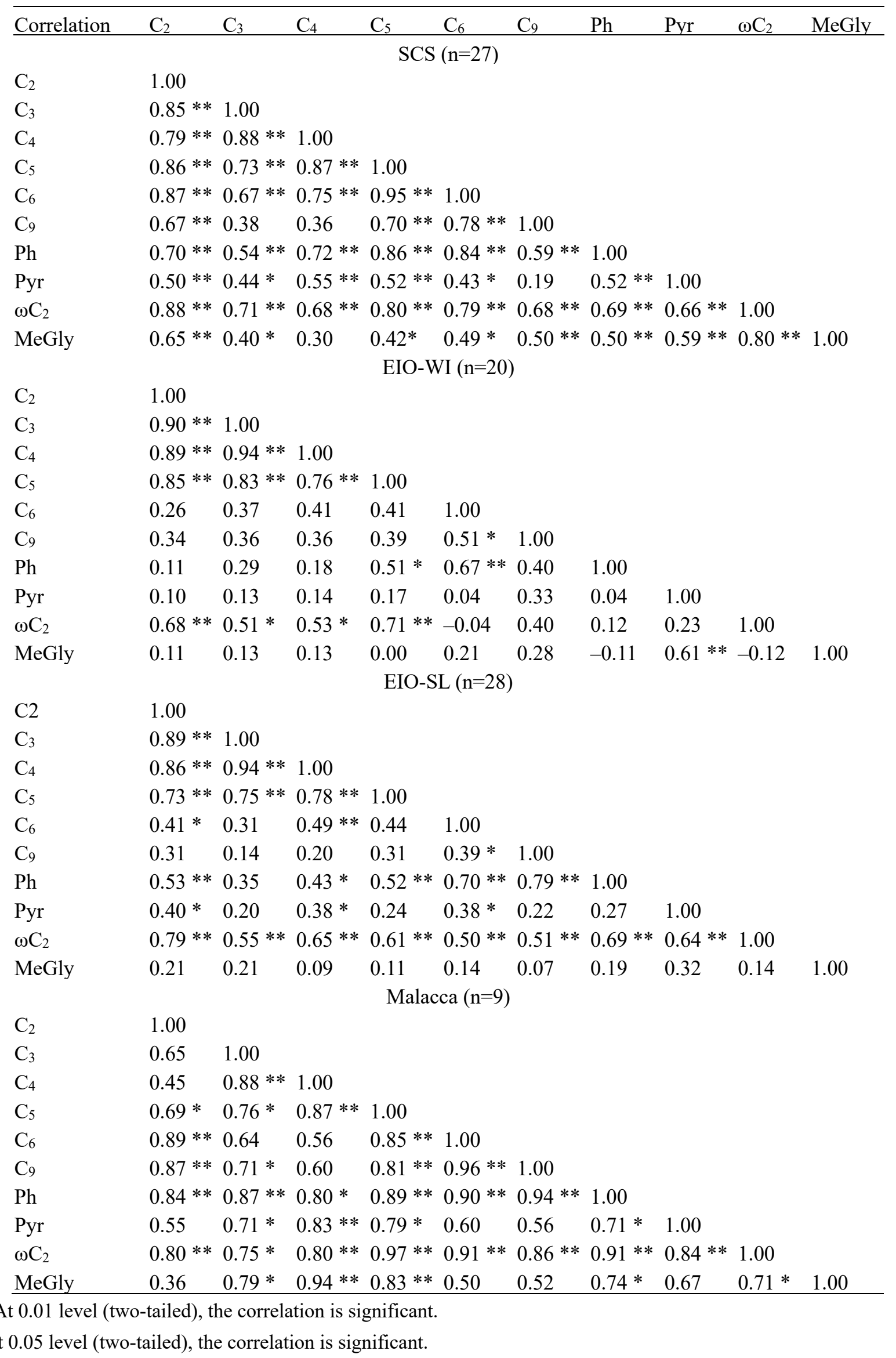


<smiles>O=C(O)C(=O)O</smiles>

(a) Oxalic acid $\left(\mathrm{C}_{2}\right)$<smiles>O=C(O)CC(=O)O</smiles>

(b) Malonic acid $\left(\mathrm{C}_{3}\right)$<smiles>O=C(O)CCC(=O)O</smiles>

(c) Succinic acid $\left(\mathrm{C}_{4}\right)$<smiles>O=C(O)CCCC(=O)O</smiles>

(d) Glutaric acid $\left(\mathrm{C}_{5}\right)$<smiles>O=C(O)CCCCC(=O)O</smiles>

(e) Adipic acid $\left(\mathrm{C}_{6}\right)$<smiles>O=C(O)CCCCCCCC(=O)O</smiles>

(f) Azelaic acid $\left(\mathrm{C}_{9}\right)$<smiles>CC(C(=O)O)C(=O)O</smiles>

(g) Methylmalonic acid $\left(\mathrm{iC}_{4}\right)$<smiles>O=C(O)C(=O)C(=O)O</smiles>

(h) Ketomalonic acid $\left(\mathrm{kC}_{3}\right)$<smiles>O=C(O)/C=C\C(=O)O</smiles>

(k) Maleic acid (M)<smiles>O=C(O)CCC(=O)CCC(=O)O</smiles>

(i) 4-Ketopimelic acid $\left(\mathrm{kC}_{7}\right)$<smiles>O=C(O)c1ccccc1C(=O)O</smiles>

(j) Phthalic acid $(\mathrm{Ph})$<smiles>O=C(O)/C=C/C(=O)O</smiles>

(I) Fumaric acid (F)<smiles>O=C(O)CC(O)C(=O)O</smiles>

(m) Malic acid $\left(\mathrm{hC}_{4}\right)$<smiles>O=CC(=O)O</smiles>

(n) Glyoxylic acid<smiles>O=CCCC(=O)O</smiles>

(o) 4-Oxobutanoic acid<smiles>CC(=O)C(=O)O</smiles>

(p) Pyruvic acid (Pyr)<smiles>C=CC=O</smiles>

(q) Glyoxal (Gly)

Figure S1. Chemical structures of selected dicarboxylic acids and other major organic compounds detected in the marine aerosols. 

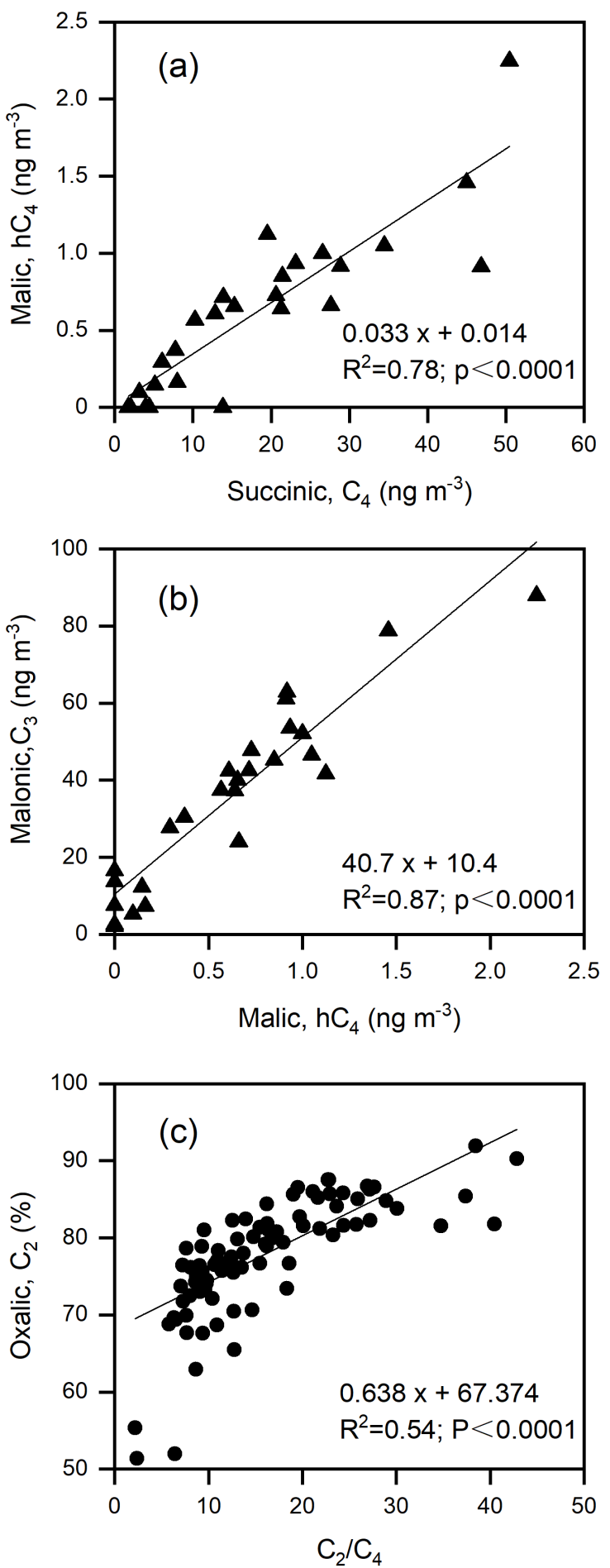

Figure S2. Scatterplots for (a) malic versus succinic acids, (b) malonic versus malic acids in aerosols collected over the SCS; (c) relative abundance of oxalic acid in total diacid mass versus $\mathrm{C}_{2} / \mathrm{C}_{4}$ ratios in aerosols collected over the all sea areas. 

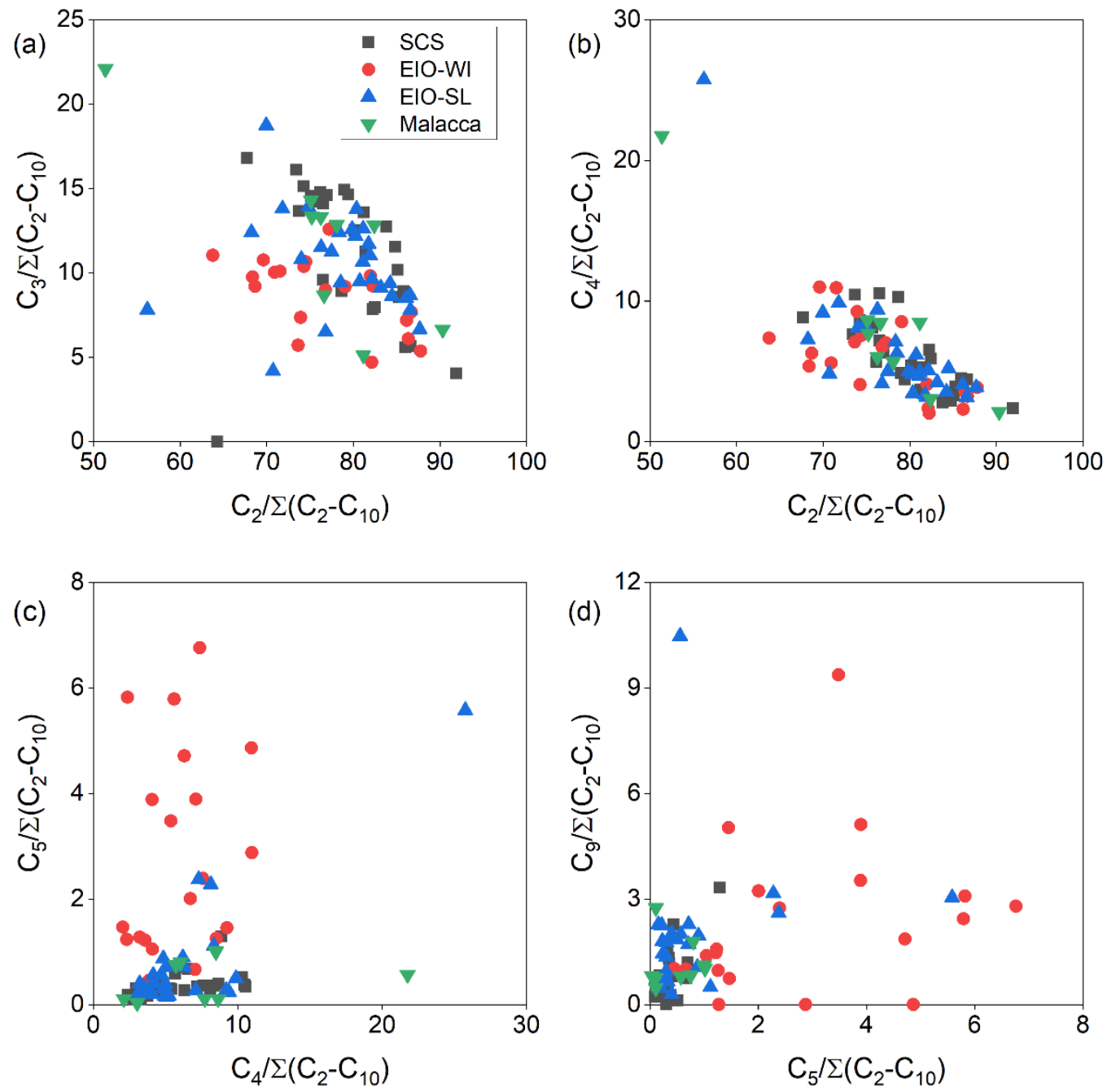

Figure S3. Scatterplots between the relative abundances of $\mathrm{C}_{2}$ in their total aliphatic homologues $\left(\Sigma \mathrm{C}_{2}-\mathrm{C}_{10}\right)$ with that of (a) malonic acid and (b) succinic acid. Likewise, scatterplots showing the relative abundances of $\mathrm{C}_{5}$ in $\Sigma \mathrm{C}_{2}-\mathrm{C}_{10}$ with those of (c) $\mathrm{C}_{4}$ and (d) $\mathrm{C}_{9}$ diacids in TSP samples collected during the NORC2015-10 cruise. 


\section{REFERENCES}

Gantt, B., Meskhidze, N., Zhang, Y., and Xu, J.: The effect of marine isoprene emissions on secondary organic aerosol and ozone formation in the coastal United States, Atmospheric Environment, 44, 115-121, 2010.

Kawamura, K., and Sakaguchi, F.: Molecular distribution of water soluble dicarboxylic acids in marine aerosols over the

Pacific Ocean including tropics, Journal of Geophysical Research Atmospheres, 104, 3501-3509, 1999.

Kourtchev, I., Copolovici, L., Claeys, M., and Maenhaut, W.: Characterization of atmospheric aerosols at a forested site in Central Europe, Environmental science \& technology, 43, 4665-4671, 2009.

Nguyen, T. B., Bateman, A. P., Bones, D. L., Nizkorodov, S. A., Laskin, J., and Laskin, A.: High-resolution mass spectrometry analysis of secondary organic aerosol generated by ozonolysis of isoprene, Atmospheric Environment, 44, 1032-1042, 2010.

90 Yang, L., Ray, M. B., and Liya, E. Y.: Photooxidation of dicarboxylic acids-Part II: Kinetics, intermediates and field observations, Atmospheric Environment, 42, 868-880, 2008. 